\title{
GASTRIC CYSTS OF THE MEDIASTINUM WITH A REPORT OF TWO CASES
}

\author{
BY \\ AUDREY MATHESON, GORDON CRUICKSHANK and W. J. MATHESON \\ From the Children's Hospital, Leicester Royal Infirmary, and Leicester Chest Unit
}

(RECEIVED FOR PUBLICATION JUNE 3, 1952)

The occurrence of an intra-thoracic cyst lined with gastric mucosa is a rarity, only 31 previous cases having been reported (Table 1), although a number of others lined with mixed gastric and intestinal or respiratory mucosa have been described. Their recognition, however, is important since early surgical removal is curative. If unrecognized and causing symptoms death in infancy is usual. These points are illustrated by the following two cases.

\section{Case Reports}

Case 1. Keith H. was aged 9 weeks on admission to the Children's Hospital, Leicester Royal Infirmary, on May 21, 1949, because of repeated haemoptyses.

He was the second child of healthy parents, and was born at term after a normal delivery, weighing $6 \frac{1}{2} \mathrm{lb}$. The first child had been stillborn. On discharge from the maternity hospital at 2 weeks he had a slight cold which later 'settled on his chest'. At $3 \frac{1}{2}$ weeks he had his first haemoptysis and this had recurred practically every day since. At 6 weeks he was admitted to another hospital where a lung abscess was suspected. An attempted bronchoscopy was unsuccessful and needling of the right lung produced no fluid. He was given a blood transfusion and transferred to the Leicester Royal Infirmary.

On examination the temperature was normal, the pulse 130, and respiration 40 . The weight was $71 \mathrm{lb}$. (expected weight $9 \frac{1}{2} \mathrm{lb}$.). He was a wasted, pale, dyspnoeic baby, slightly cyanosed. The fingers were clubbed. The trachea was central, and no mediastinal shift was detected. The percussion note was impaired over the whole of the right hemithorax with bronchial breath sounds over the upper zone and diminished vesicular sounds with crepitations at the base. No other abnormal physical signs were found.

RADIOGRAPHS. There was considerable speculation at the time about the interpretation of the films but no definite conclusion was reached. Review of the films now, however, shows that their appearance would be consistent with a fluid-containing cyst in communication with a bronchus. The right hemithorax is totally opaque and contains an air-fluid level which, in the lateral view, is seen to be situated posteriorly (Fig. 1). In addition, hemivertebrae are present in the upper dorsal spine.

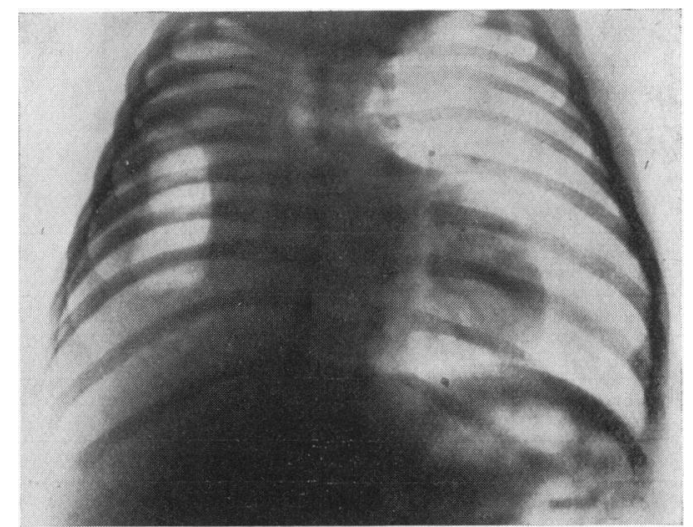

FIG. 1.-Radiograph showing air-fluid level in cyst in right hemithorax.

BRONCHOSCOPY. Bronchoscopy was performed on May 26, 1949. Vision was obscured by much mucoid secretion, but no obstruction was seen in the right bronchial tree.

Blood CounTs. The following results were obtained: On $21.5 .49, \mathrm{Hb} 51 \% ; 24.5 .49$, Hb $73 \% ; 30.5 .49, \mathrm{Hb}$ $55 \% ; 31.5 .49, \mathrm{Hb} 63 \%$ and leucocytes 15,000 (polymorphs $61 \%$; 21.6 .49 , Hb. $50 \%$.

TREATMENT. Blood transfusions were given by slow injection on May 23, May 30 and June 10 in amounts of 80,50 and $80 \mathrm{ml}$. respectively, and penicillin, 30,000 units three-hourly by mouth, from May 31 to June 23 and again from July 2 until death.

On two occasions in the first four days after admission bright red blood was discharged through the nose. A genuine haemoptysis was first observed on June 9 and recurred daily for the next week. There was then an interval of freedom until the fatal massive haemoptysis occurred on July 3. These haemoptyses were accompanied by much frothy, watery fluid. There was a severe paroxysmal cough throughout. For the first 
TABLE 1

ANAlysis of CAses Reported in the Literature

\begin{tabular}{|c|c|c|c|c|c|c|c|}
\hline & Author & & Age & $\operatorname{Sex}$ & Presenting Symptoms & Operation & Result \\
\hline 1 & Mixter and Clifford (1929) & $\cdots$ & 22 months & Male & Fever, cough, dyspnoea & Two-stage & Recovered \\
\hline 2 & Mixter and Clifford (1929) & $\cdots$ & 7 weeks & Male & Difficulty in feeding & $\begin{array}{l}\text { Cyst not located at } \\
\text { operation }\end{array}$ & Died \\
\hline 3 & Entz and Orosz (1930) & $\cdots$ & 11 months & Male & Malnutrition & Marsupialization & Died \\
\hline 4 & Fischer (1929) $\ldots$ & $\ldots$ & 6 months & Female & Cough & None & Died \\
\hline 5 & Poncher and Milles (1933) & $\cdots$ & 2 years & Male & $\begin{array}{l}\text { Attacks of abdominal pain and } \\
\text { melaena }\end{array}$ & Thoracotomy & Died \\
\hline 6 & Böss (1937) & $\cdots$ & 3 years & Male & Haemoptysis & Two-stage & Died \\
\hline 7 & Seydl (1938) & $\cdots$ & 3 months & Female & Cough and haemoptysis & None & Died \\
\hline 8 & Lowry and Moorman (1938) & $\cdots$ & 4 months & $\begin{array}{l}\text { Not } \\
\text { stated }\end{array}$ & Dyspnoea & Thoracotomy & Died \\
\hline 9 & Nicholls (1940) & $\cdots$ & 8 years & Female & Chronic empyema & One-stage excision & Recovered \\
\hline$\overline{10}$ & $\begin{array}{l}\text { Ladd and Gross (1940) } \\
\text { (Case 2) }\end{array}$ & $\bar{x}$ & 11 months & $\begin{array}{c}\text { Not } \\
\text { stated }\end{array}$ & $\begin{array}{c}\text { Difficulty in swallowing and } \\
\text { dyspnoea }\end{array}$ & Attempted excision & Recovered \\
\hline 11 & $\begin{array}{l}\text { Ladd and Gross (1940) } \\
\text { (Case 4) }\end{array}$ & 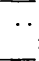 & 7 months & $\begin{array}{c}\text { Not } \\
\text { stated }\end{array}$ & $\begin{array}{c}\text { Difficulty in swallowing and } \\
\text { dyspnoea }\end{array}$ & Excised & Died \\
\hline 12 & $\begin{array}{l}\text { Ward and Krahl (1942) } \\
\text { (Case 2) }\end{array}$ & $\ldots$ & 9 weeks & Male & Cough and haemoptysis & None & Died \\
\hline$\overline{13}$ & $\begin{array}{l}\text { Schwarz and Williams (1942) } \\
\text { (Case 1) }\end{array}$ & $\bar{x}$ & 4 months & Male & Cyanosis and dyspnoea & One-stage excision & Died \\
\hline 14 & Wyllie and Pilcher (1943) & $\cdots$ & 1 year & Female & Poor weight gain & One-stage excision & Recovered \\
\hline$\overline{15}$ & $\begin{array}{l}\text { Ladd and Scott (1944) } \\
\text { (Case 3) }\end{array}$ & $\cdots$ & 7 months & Female & Cough and fever & Several operations & Died \\
\hline 16 & $\begin{array}{l}\text { Ladd and Scott (1944) } \\
\text { (Case 4) }\end{array}$ & $\cdots$ & 3 weeks & Male & $\begin{array}{l}\text { None: detected by routine radio- } \\
\text { graph }\end{array}$ & $\begin{array}{l}\text { Marsupialization } \\
\text { followed by three } \\
\text { other operations }\end{array}$ & Recovered \\
\hline 17 & $\begin{array}{l}\text { Ladd and Scott (1944) } \\
\text { (Case 5) }\end{array}$ & $\bar{\ldots}$ & 2 years & Male & Haemoptysis & Several operations & Recovered \\
\hline 18 & Laipply (1945) & . & 1 day & Male & None & None & Died \\
\hline 19 & Steele and Schmitz (1945) & $\ldots$ & 15 years & Female & $\begin{array}{l}\text { None: detected by routine radio- } \\
\text { graph }\end{array}$ & One-stage excision & Recovered \\
\hline 20 & Valle and White (1946) & $\cdots$ & 22 months & Female & Cough, cyanosis, haemoptysis & Thoracotomy & Died \\
\hline 21 & Christoffersen (1947) $\ldots$ & 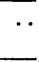 & 22 months & Male & $\begin{array}{l}\text { None: detected by routine radio- } \\
\text { graph }\end{array}$ & One-stage excision & Recovered \\
\hline 22 & Davidson and Brown (1947) & $\cdots$ & 5 years & Female & Failure to gain & One-stage excision & Recovered \\
\hline 23 & Davis and Salkin (1947) & 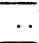 & 14 years & Female & Pain in right chest & One-stage excision & Recovered \\
\hline 24 & Jones (1947) (Case 1) & $\cdots$ & 2 months & Male & Failure to gain & None & Died \\
\hline$\overline{25}$ & Jones (1947) (Case 2) & $\cdots$ & 19 months & Male & $\begin{array}{l}\text { None: detected by routine radio- } \\
\text { graph }\end{array}$ & One-stage excision & Recovered \\
\hline 26 & Ehler and Atwell (1948) & $\cdots$ & 15 months & Male & Cough and hacmatemesis & One-stage excision & Recovered \\
\hline 27 & Bickford (1949) & F & 3 years & Male & Attacks of cough and dyspnoea & One-stage excision & Recovered \\
\hline 28 & Doub (1951) .. & $\ldots$ & 20 years & Female & $\begin{array}{l}\text { None: detected by routine radio- } \\
\text { graph }\end{array}$ & One-stage excision & Recovered \\
\hline 29 & Oterdoom (1951) & $\cdots$ & 14 years & Female & $\begin{array}{l}\text { None: detected by routine radio- } \\
\text { graph }\end{array}$ & One-stage excision & Recovered \\
\hline 30 & Van Aken (1951) (Case 1) & $\bar{\cdots}$ & 3 years & Male & Cough and haemoptysis & One-stage excision & Recovered \\
\hline$\overline{31}$ & Van Aken (1951) (Case 2) & $\cdots$ & 1 year & Male & Cough and pneumonia & One-stage excision & Recovered \\
\hline
\end{tabular}

three weeks there was an irregular pyrexia to $102^{\circ} \mathrm{F}$.; the temperature was normal for the next two weeks but fever recurred in the last week.
The infant gained slowly and with fluctuations, the last weight recorded being $8 \frac{1}{2} \mathrm{lb}$. on June 30 .

NECROPSY. This was performed on July 4, 1949. 
Abnormal findings were confined to the right lung. A cyst $1 \frac{1}{2}$ in. in diameter was attached to the dorsal segment of the right lower lobe (Fig. 2). This cyst, which was adherent on its posterior aspect to the parietal pleura, presented a lining of mucosa resembling that of the stomach and communicated with a cavity in the adjacent lung through a narrow channel also lined with mucosa. Immediately surrounding the opening of the communicating channel the pulmonary cavity was lined with mucosa but elsewhere the lining was of granulation tissue, except for a portion near a communicating bronchus lined with epithelium. The surrounding lung was collapsed and showed acute purulent infection. Blood clot filled the cavity in the lung; there was a small amount in the cyst.

Microscopically the cyst wall (Fig. 3) was composed of two layers of smooth muscle, muscularis mucosae and gastric mucosa. Continuity of the epithelial and muscular layers was demonstrable along the communicating channel up to a point just beyond the entrance into the cavity in the lung. Haemorrhage had arisen from the wall of this cavity in an area which gave the appearance of a peptic ulcer. Near the communicating bronchus the epithelium lining the cavity showed squamous metaplasia.

The pulmonary arteries showed considerable medial hypertrophy.

Case 2. M.N. was aged 3 months on admission to the Leicester Chest Unit on July 18, 1952.

$\mathrm{He}$ is the first child of healthy parents, and was delivered at term by forceps, weighing $6 \mathrm{lb}$. He was well until 7 weeks old, when he developed bronchitis: the cough persisted and at 10 weeks he had a haemoptysis. After this he became febrile and very dyspnoeic and refused

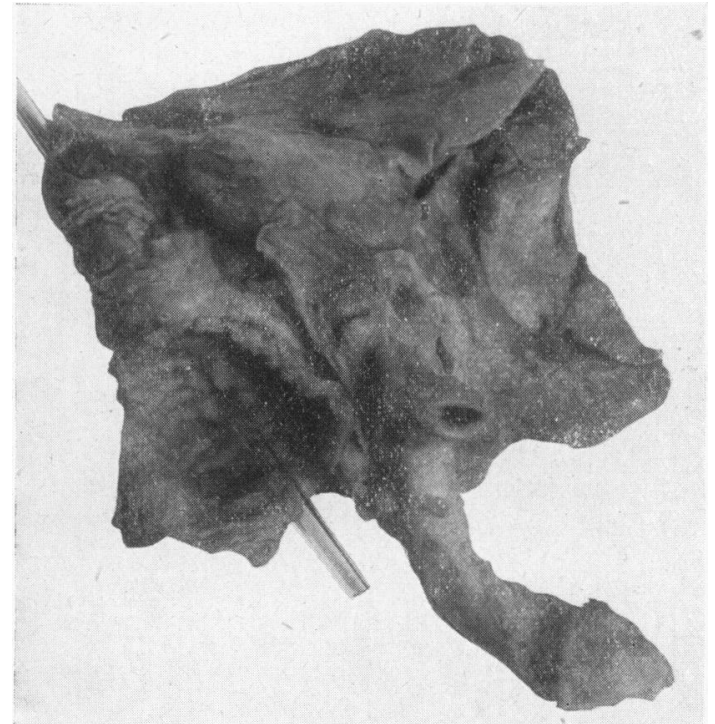

FIG. 2.-Photograph of right lung with cyst attached showing lining of gastric mucosa. The glass rod is in the channel connecting the two portions of the cyst.

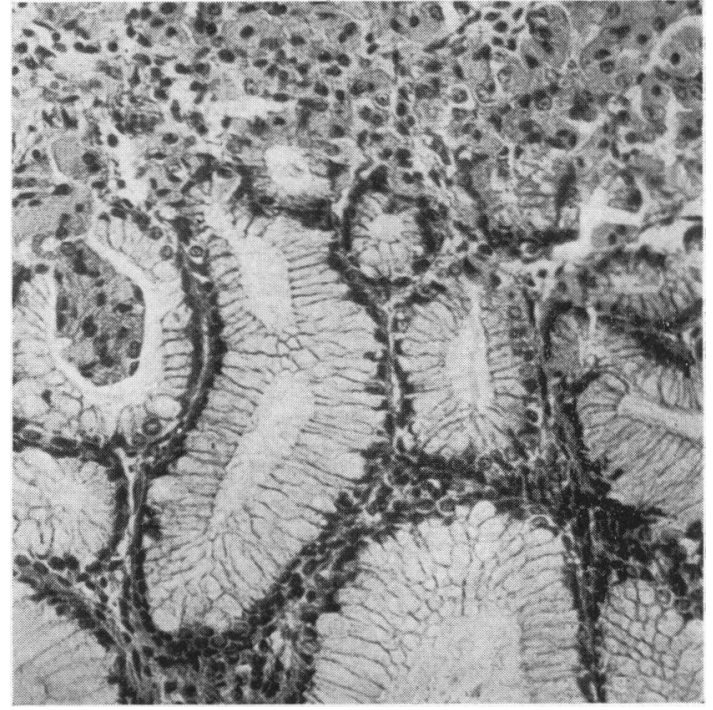

FIG. 3.-Photomicrograph of wall of cyst (haematoxylin and eosin $\times 190)$ showing gastric mucosa.

feeds. He was therefore admitted two days later on July 4, 1952, to another hospital. Under treatment the respiratory distress subsided but his general condition did not improve and he had further haemoptyses. $\mathrm{He}$ was transferred to the Leicester Chest Unit on July 18, 1952.

On examination his temperature was $100^{\circ} \mathrm{F}$., the pulse 170 and respiration 40 . Weight was $10 \frac{1}{2} \mathrm{lb}$. He was a pale, cyanosed, dyspnoeic infant. He had an external angular dermoid cyst over the right eye. The percussion note was impaired over the whole of the left side with diminished vesicular breath sounds accompanied by many crepitations. During examination he coughed up blood. This sputum gave an acid reaction with litmus paper. No other abnormality was detected.

A radiograph on admission showed that the whole of the left hemithorax was opaque. Hemivertebrae of the third to the seventh dorsal segments were also seen. On admission the red blood cells were $3,600,000$, $\mathrm{Hb} 68 \%$ and leucocytes 18,700 (54\% polymorphs).

In view of the haemoptysis and history of persistent pulmonary infection a diagnosis of a gastric cyst of the mediastinum was made and immediate operation decided on after an intravenous blood drip had been set up.

First OPERATION. G.C. operated on July 18 with the infant in the lateral position. The chest was opened through the bed of the resected sixth left rib. The lung was extensively adherent. A cystic structure was found lying in the interlobar fissure. The lining of the cyst appeared to be of mucous membrane. In its base, and communicating with the lung, was a punched-out hole having the appearance of a peptic ulcer. The cyst was removed by sharp dissection. Further inspection of the pleural cavity revealed a second cyst lying in the paravertebral gutter at the level of the sixth rib but, owing 
to the baby's poor general condition, it was considered prudent to leave this cyst, as it appeared to be uncomplicated, for removal at a subsequent operation. The chest was then closed.

On the day after operation the baby's general condition was much improved. Haemoglobin was $90 \%$. A radiograph of the chest on July 22 showed considerable clearing of the left lung field. He began to gain weight, and penicillin, which had been given since admission, was stopped on July 29. On August 2, however, he began to lose weight and again became dyspnoeic. The percussion note at the left apex again became impaired and penicillin was restarted. On August 6 he had a haemoptysis and next day a lateral radiograph of the chest showed a small fluid level situated posteriorly in the left chest in the position of the cyst noticed at operation. It was therefore thought advisable to remove this cyst.

Second Operation. The previous incision was re-opened on August 7 by G.C. The cyst was encountered lying deeply buried behind the aorta and oesophagus. It was removed by scissors dissection.

Progress following this operation was uninterruptedly good. The baby gained weight and had no further haemoptyses. A chest radiograph on August 12 showed almost complete aeration of the left lung. When he was discharged on August 27 at the age of $4 \frac{1}{2}$ months he weighed $12 \mathrm{lb}$. $13 \mathrm{oz}$. Haemoglobin was $99 \%$.

Pathological Reports. Dr. D. B. Cruickshank reported as follows:

Specimen from First Operation. 'Microscopically the cyst wall is mainly composed of unhealthy granulation tissue with a zone of older fibrosis beneath this and beyond inflamed lung. In places in the cyst wall can be seen open crypts lined with cuboidal epithelium with more deeply placed transversely cut glandular acini. There are also some isolated strands of polygonal cells suggestive of secretory epithelium. The picture is consistent with that of an inflamed necrosing gastric mucosa but it is impossible to affirm that the structure is in fact gastric mucosa.'

Later, comparing this section with that of the second cyst, Dr. Cruickshank reported that he considered that the two were of identical structure.

Specimen from Second Operation. 'Macroscopically the cyst (Fig. 4) measures $3 \times 3 \times 2.5 \mathrm{~cm}$. and has a smooth exterior except for rough attachment areas. Its wall is $0.5 \mathrm{~cm}$. thick, has an outer areolar, intermediate white "cartilaginous" and an inner thick ridged mucosal layer. The "cartilaginous" layer is $0.4 \mathrm{~cm}$. thick over part of the wall.

Microscopically this is a classic gastric cyst (Fig. 5). The structure of the lining and wall has all the features of a fundal mucosa and musculature, except that the three plain muscle layers have undergone some type of hyalo-degeneration accounting for the "cartilage"-like appearance mentioned in the macroscopic description. There is no evidence of inflammation and all histological structures are very clearly defined.'

\section{Discussion}

A number of hypotheses have been advanced to explain the origin of intra-thoracic gastric cysts ; the most generally accepted and, it seems to us, the most likely explanation is that they arise from a bud pinched off from the embryonic foregut (Mixter and Clifford, 1929). In the $4 \mathrm{~mm}$. embryo the lungs and trachea are represented by a mass attached to the ventral surface of the oesophagus: the lower part of this mass constitutes the site of the division of the bronchi from the trachea whose cavity is still in free communication with the

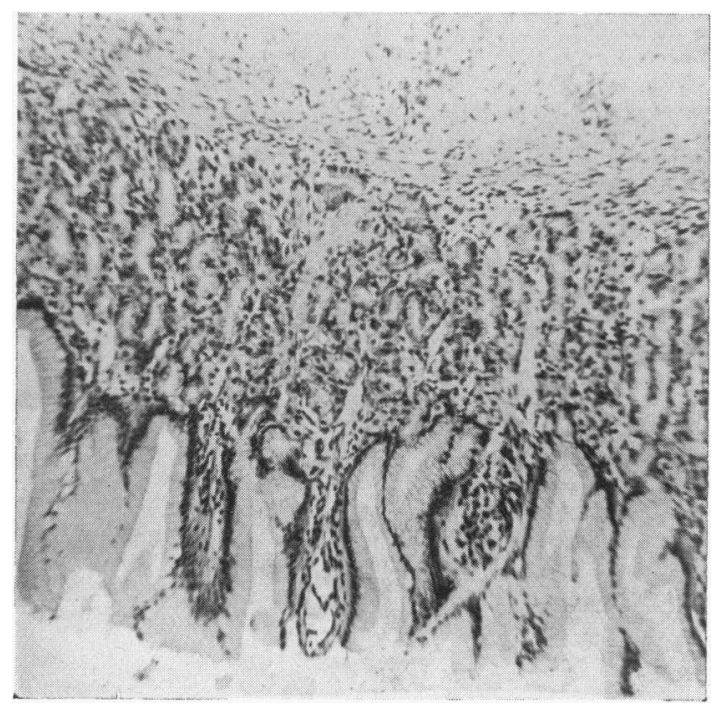

Fig. 5.-Low power view of wall of cyst shown in Fig. 4. 
oesophagus. The trachea becomes separated from the oesophagus by the downward growth of the lung buds and the upward extension of the notch between the lung buds and oesophagus. At this stage an outbud of foregut containing entoderm and mesoderm and destined to become stomach could be pinched off. This hypothesis would also explain the almost invariable situation of these cysts on the right since the stomach normally rotates to the right during development.

Symptoms can be divided into three groups, those resulting from pressure, those from functional activity of the cyst and those from infection. Both our cases showed all three. In the first group are cough, dyspnoea, cyanosis, wheezing and occasionally pain; in the second haemoptysis; and in the third pyrexia and interference with nutrition. Pressure symptoms are usually continuous but may occur in attacks which, Olenik and Tandatnick (1946) suggest, are due to varying amounts of secretion in the cyst. Presenting symptoms are usually those of pressure and/or infection which frequently occurs (Jones, 1947). Haemoptysis as a presenting symptom is unusual but has been noted in other cases. It is difficult in young babies to distinguish haemoptysis from haematemesis, a difficulty encountered by us in Case 1 and noted also by other observers (Ladd and Scott, 1944). In $75 \%$ of the reported cases symptoms have started in the first year of life (Jones, 1947): seven cases (Table 1) have only been detected by routine radiographs, and Valle and White (1946) consider that in those cases in which symptoms do not occur early the cysts are functionally inactive. It seems probable that the fluid coughed up with the blood in Case 1 was gastric juice but no tests were made: in Case 2 the fluid was acid to litmus.

Neither physical signs nor the $x$-ray picture are characteristic and superadded infection may make identification of the cyst difficult. A cyst situated posteriorly and on the right may suggest a gastric cyst, since all those reported have been in this situation except for two on the left described by Jones (1947) and our Case 2: they are usually in the middle third of the thorax.

It is naturally impossible to make a correct preoperative diagnosis of a gastric cyst unless functional activity can be demonstrated. The occurrence of haemoptysis in a young infant is very suggestive since it is at this age a symptom rarely encountered. Tapping the cyst to demonstrate the activity of its contents as has been done (Jones, 1947); Mixter and Clifford, 1929; Ehler and Atwell, 1948) is not advisable, not only on account of the risks inherent in such an operation, but because gastric juice leaking along the needle track may cause digestion of surrounding structure as has been noted in the skin following marsupialization of the cyst (Thompson, 1947). The diagnosis of a bronchial angioma was considered in Case 1. Bronchoscopy was unhelpful because of the large amount of mucus present and thoracotomy was not considered advisable in view of the infant's poor general condition. The correct diagnosis, as in most of the other recorded cases, was not suspected but in retrospect this was a typical case. In Case 2, profiting by experience, the correct diagnosis was made on the strength of the haemoptysis, the acid sputum and persistent pulmonary infection. It is of interest that both cases showed hemivertebrae, an associated abnormality noted by other observers.

Most gastric cysts are unilocular and single; in Case 1 the cyst was bilocular and peptic ulceration occurred in only one of the portions, rupturing into the lung and causing the haemoptysis. Gastric cysts are usually about the size of those in the present cases but Poncher and Milles (1933) recorded one $12 \mathrm{~cm}$. in diameter and Wyllie and Pilcher (1943) comment on the difficulty of distinguishing a large cyst from an effusion. Rarely, more than one cyst, as in Case 2, may be found (Poncher and Milles, 1933; Ward and Krahl, 1942).

In the past operative removal has been attended by a high mortality but in recent years, with improvement in thoracic surgery, more successful results have been obtained. Before 1940 operation was performed in six cases of which only one recovered. Since 1940 removal of the cyst has been carried out in 20 cases, in 16 of which a successful outcome has resulted: the youngest patient on whom operation has been performed successfully was 3 weeks old (Ladd and Scott, 1944). Most authorities agree that the operation of choice is removal in one stage, but Ladd and Scott (1944) and Ladd and Gross (1940) advise marsupialization first followed by removal later. There is, however, a danger of excoriation of the skin with this method. Ladd and Scott (1944) stress the intimate attachment of these cysts to the oesophagus and state that they may share a common muscular wall, but the experience of other observers seems to indicate that this is unusual.

We wish to thank Dr. J. Vernon Braithwaite for permission to report Case 1 , Dr. G. $\mathbf{H}$. Valentine for referring Case 2, Dr. J. N. Dearnally for the post-mortem report of Case 1, Dr. D. B. Cruickshank for the pathological reports on and photomicrograph of Case 2, Miss C. van Dorp, F.R.C.S., for some of the translations, and Mr. E. V. Willmott for the photomicrograph of Case 1. 


\section{REFERENCES}

Aken, W. van (1951). Ned. T. Geneesk., 95, 564.

Bickford, B. J. (1949). Brit. J. Surg., 36, 410

Böss, C. (1937). Virchows Arch. path. Anat., 300, 166.

Christoffersen, J. C. (1947). Acta chir. scand., 96, 12.

Davidson, L. R. and Brown, L. (1947). J. thorac. Surg., 16, 458

Davis, E. W. and Salkin, D. (1947). J. Amer. med. Ass., 135, 218.

Doub, H. P. (1951). J. Fac. Radiol., Lond., 2, 302.

Ehler, A. A. and Atwell, S. (1948). J. thorac. Surg., 17, 809.

Entz, B. and Orosz, D. (1930). Frankfurt. Z. Path., 40, 229.

Fischer, W. (1929). Virchows Arch. path. Anat., 275, 711.

Jones, J. C. (1947). West. J. Surg., 55, 610.

Ladd, W. E. and Gross, R. E. (1940). Surg. Gynec. Obstet., 70, 295.

and Scott, H. W. (1944). Surgery, 16, 815.

Laipply, T. C. (1945). Arch. Path., Chicago., 39, 153.
Lowry, T. and Moorman, L. J. (1938).Amer. Rev. Tuberc., 38, 27. Mixter, C. G. and Clifford, S. H. (1929). Ann. Surg., 90, 714.

Nicholls, M. F. (1940). Brit. J. Surg., 28, 137. Olenik, J. L. and Tandatnick, J. W. (1946). Amer. J. Dis. Child., 71,

Oterdoom, H. J. (1951). Ned. T. Geneesk., 95, 566.

Poncher, H. G. and Milles, G. (1933). Amer. J. Dis. Child., 45, 1064.

Schwarz, H. and Williams, C. S. (1942) J thorac. Surg., 12, 117.

Seydl, G. N. (1938). Frankfurt. Z. Path., 52, 346.

Steele, J. D. and Schmitz, J. (1945). J. thorac. Surg., 14, 403.

Thompson, J. V. (1947). Int. Abstr. Surg., 84, 195.

Valle, A. R. and White, M. L. (1946). Ann. Surg., 123, 377.

Ward, I. M. and Krahl, J. B. (1942). Amer. J. Dis. Child., 63, 924.

Wyllie, W. G. and Pilcher, R. S. (1943). Archives of Disease in Childhood, 18, 34. 